\title{
Investigating the Relationship between Marketing Knowledge Sharing and Developing Competitive Advantage (Case Study: Arak Shazand Petrochemical)
}

\author{
Mohamad Reza Hamidizadeh ${ }^{1} \&$ Parinaz Aghaei Meibodi ${ }^{2}$ \\ ${ }^{1}$ Professor, Management and Accounting Faculty, Shahid Beheshti University, Iran \\ ${ }^{2}$ Department of Business Management, Master of International Business, Shahid Beheshti University, Iran \\ Correspondence: Mohamad Reza Hamidizadeh, Professor, Management and Accounting Faculty, Shahid \\ Beheshti University, Iran. E-mail: E-mail: m-hamidizadeh@sbu.ac.ir
}

Received: September 2, 2016

Accepted: September 13, 2016

Online Published: October 17, 2016

doi:10.5539/mas.v11n2p8

URL: http://dx.doi.org/10.5539/mas.v11n2p8

\begin{abstract}
The aim of this study is to investigate the relationship between marketing knowledge sharing and developing competitive advantage. This research is an applied objective research and data collection method of description-correlation nature the subjects under study by this research are employees of Arak Shazand petrochemical industry. The sample size was estimated 90 people. The method is stratified random sampling. A standard questionnaire was used to collect data. Marketing knowledge sharing questionnaire of Moghimi and Ramazani (2011) contains 17 items and developing competitive advantage questionnaire of Hill and Jones (2010) contains 16 items. Logical validity (face and content) of questionnaires was reviewed and approved through several university professors and several experts of this industry. Also, construct validity was reviewed and approved by confirmatory factor analysis using AMOS software. Cronbach's alpha coefficient of 0.7 was obtained for variables that indicate internal consistency of items and acceptable reliability of the questionnaire. The research hypothesis test using univariate linear regression was performed with application of SPSS software. The results showed that, given that the $t$-statistic value is greater than $1.96(t=6.48)$, the relationship between two variables, competitive advantage and marketing knowledge sharing was significant at the $5 \%$ error level . $(P-$ Value $<0.05)$ Standard regression coefficient $(0.57)$ also specified the share of independent variable in explaining the changes of dependent variable so that for every one unit increase in variable of marketing knowledge sharing, competitive advantage increases 0.57 .
\end{abstract}

Keywords: knowledge sharing, marketing, competitive advantage, employee, Arak Shazand petrochemical industry

\section{Introduction}

Knowledge has been one of the issues mentioned in the field of management in recent years. Knowledge management and creativity play a key role in management and increasing competitive advantage in organizations. Knowledge (insight and awareness) is a stable source of profits for organization in the growing world of competition. Knowledge sharing has a vital role in the knowledge management because knowledge management in the division and sharing with others is developed and sustained. Although from the existing knowledge in knowledge management exists a huge chunk, but in relation to the knowledge sharing, little information is available and studies related to marketing knowledge sharing are scarce. The main reason of searching for factors' affecting this area is this: each company involves two characteristics: creativity and marketing. Marketing is a covering border area covered in company that relates company to customers, competitors and other marketing factors. Marketing knowledge is a new field in the marketing and in this filed has had growing developments. (Hamidizadeh \& Azizi, 2009).

Companies design their 4Ps (Product -Price -Promotion -Place) and STP (segmentation, targeting, positioning) based on their information about customers and competitors. Knowledge about customers includes the needs, desires, satisfaction and factors influencing their loyalty. Knowledge about competitors leads to complete recognition of them namely knowledge of their strategies and programs. Final knowledge that is related to the company about 4Ps and STP of the company based on its strategies. Then the company tries to find a proper 
relationship between customers and competitors (Hamidizadeh and Azizi, 2009).

Source of knowledge and its dissemination in the processes, norms and practices of knowledge within organizations are merged. Knowledge is source of power, but knowledge sharing is source of great powers, because knowledge sharing causes knowledge to increase and ultimately leads to financial benefits.

If people share information, views, effective practices, experiences, tastes and lessons learned the performance of different parts of organization increases. Alternatively, they can also share their common and non-common sense. (Hamidizadeh \& Azizi, 2009).

This study attempts to investigate the marketing knowledge sharing and developing competitive advantage at personal and micro level in Iran's selected industry (petrochemical industry). This industry is one of the most important industries in competitive field in Iran.

\section{Theoretical Foundations}

\subsection{Competitive Advantage}

Competitive advantage is one of the basic concepts in international business that determines the competitive position of the organization and enables it to create the defensive position against competitors. An organization gains the competitive advantage when it creates a great value for its customers compared with other competing organizations. Of course, there are two distinct types of competitive advantage. The first one is cost advantage that organizations provide their products and services with a low cost and this is related to low costs of production, procurement, and distribution and like these. The second one is distinctive advantage that customers observe more basic difference in product features and organization than competitors.

In fact, competitive advantage is the understanding of competitive strategy through low cost or distinction through the creation of value. Advantage requires cost of systematic efforts of organization to increase its efficiency whereas the distinctive advantage is considered as the advantages of product and services, so that with innovation, increasing the quality of product or services and also quick response to customers' needs and meeting their expectations could be possible. Prominent scholars and researchers of marketing consider competitive advantage as the organization's ability to execute one or more ways that competitors cannot face it. Competitive advantage is vital for the survival and development of the organization in the market. If organization is able to reach its target and maintains its survival in the market continually, being aware with knowledge of the marketing activities of competitors and comparing them with its activities also through the development of competitive special mechanisms it can achieve competitive advantage and overcome the competitors in the market (Dolat Abadi et al., 2011).

\subsection{Knowledge Sharing}

Sharing knowledge that has not been well defined in the literature, partly because of the field of research has not been so active (Bowman et al., 2006). Moreover, this issue is partly due to attention to sharing. Knowledge sharing happens in organization when members want knowledge from other members to solve their problems. Dixon noted that "common knowledge" is a knowledge that employees learn from carrying out organizational tasks. Moreover, he showed that explicit and tacit knowledge requires different processes for sharing. Finally, (Bartoli et al., 2002) defined knowledge sharing as: People who share information about the organization, ideas, suggestions, expertise with each other. So, it is observed that knowledge can be explicit or implicit. Explicit knowledge is expressed in words and numbers, and easily communicated and shared, in the form of hard data, scientific formulas, codified procedures or universal principals. This knowledge is synonymous with computer codes, chemical formula, or a set of general rules (Nanoka, 1995). This is a knowledge that can easily be made in advance, to be placed in books, reported, and used as guidance, etc. This kind of knowledge is best transmitted through the transfer of technology (Vasco \& Faraj, 2000). This view of knowledge is deeply rooted in Western management philosophy that sees the organization as a data processing machine. In contrast, explicit knowledge is the concept of tacit knowledge. Tacit knowledge is very personal and hard for formalizing; making it is difficult for communicating and sharing with others (at least not through impersonal communication methods). Intuition and feeling are in this category of tacit knowledge. In addition, tacit knowledge is rooted severely in practice and personal experience, as well as ideas, values and feelings and covers them too (Nonaka, 1995). Ultimately, it is the expertise of a person (Fish \& Bandar 2000). Nanook suggested that tacit knowledge can be transferred through social processes, observation and apprenticeship requiring maximum opportunity for both sources and recipient to work alongside it. So, sharing knowledge, whether explicit or implicit, requires efforts as part of individual activities to do so.

Not only share knowledge requires efforts on the part of the individual sharing but also includes a confronting 
element. This issue differ knowledge sharing from information sharing. While knowledge sharing includes confronting elements, information sharing about management is to make available information to all members of the organization and it can be one-side and non-requested.

\subsection{The Empirical Record}

The Rifua et al (2013) conducted a study on the positioning of infrastructure components of implementing knowledge sharing in the insurance industry where they investigated the factors influencing knowledge sharing and how to implement it in the insurance industry. Their model is shown in Figure 1

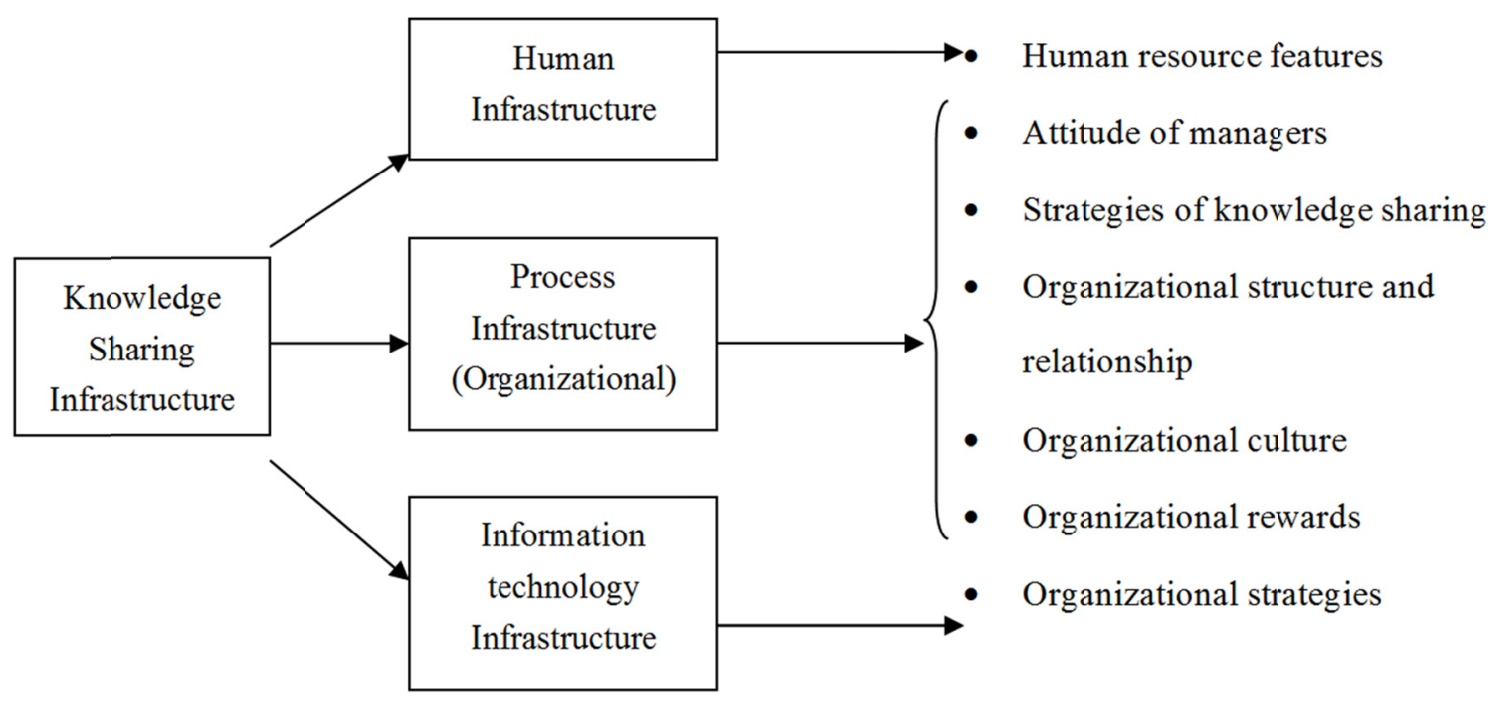

Figure 1. The conceptual model of positioning infrastructure components of implementing knowledge sharing

(Rifua et al., 2013)

\section{Results and the related discussions}

Human infrastructure: establishing appropriate mechanisms in recruitment process and taking into account criteria such as the ability to do teamwork, interpersonal and written communication skills, tendency to participate in sharing and helping others and commitment to the organization during the selection of human resources; Holding workshops and courses to increase the level of interpersonal and written communication skills of employees and familiarize them with the importance and the role of knowledge sharing in individual and organizational promotion.

Process Infrastructure (organizational): training or selecting committed leaders and managers as an effective factor in successful operating of knowledge sharing, considering the training courses of new recruits beside experienced forces of organization, more encouraging of employees to hold continuous by colleagues workshops training; Providing the grounds for scientific lectures by employees on the various occasions in specialized areas of activities, meetings, training courses and seminars by the Central Organization for agencies of staff and branches across the country and encourage employees to actively participate in these programs; Motivate employees and enhance their ability to write articles for internal newsletters and publications of organization or submission of articles to specialized conferences of related insurances; Set up a think tank in insurance companies in order to solve the current problems of organization and consultation and discussion about the future plans and objectives of the organization;

Holding informal meetings periodically to discuss and consider successful and unsuccessful experiences of employees; focusing on teamwork, the creation of specialized insurance groups and inter-agency groups and working groups a factor for offering and the application of knowledge sharing within the organization; Creating an organizational structure with the characteristics of decentralization in decision-making, less laws and regulations, more flexibility, more horizontal structure or network, more informal communication for improving knowledge sharing; Organizing business units so that the people who have worked continuously with each other or have got the most benefit form exchanging knowledge with their colleagues, be together; effective and close communication of manager with his subordinates; creating a Q \& A culture so that employees participate in the 
discussion of the knowledge and new problems that arise, and give appropriate feedback to each other; creating a culture in organization that makes the knowledge sharing process necessary and possible among all employees collectively and commonly, from managers to the operational employees in all the activities of organization; strengthening active involvement of employees in solving problems of organization and creating an atmosphere of mutual trust to reach this involvement maker policies and strategies that help free expression of ideas and opinions, open communication of members, effective solution of conflicts, cooperation, trust and mutual respect and understanding views of each other in working groups; Considering the financial and non-financial rewards. In this way employees who do not tent to share their knowledge with colleagues, are encouraged; Revising indicators of performance appraisal and reward of employees with the aim of honoring the sharing of knowledge and the use of systematic and periodic written evaluations, with to the possibility of promoting the employees who are trying to share knowledge to higher levels; More attention of the organization in designing strategic plans and policies that facilitate the knowledge sharing process and clarify the goals and plans set in the dimensions of organizational knowledge for all employees.

Information and communication technology infrastructure: The knowledge base of the unit should be formed established so that speeches, reports and technical documents, personnel experiences, superior performances of organization, lessons learned from organizational projects are stored in it. Abase of professional specialized descipliens, specific skills and research interests of staff should be formed and various tactics to make communication between people with common interests be thought of and even for some time after the retirement of efficient forces of organization, it could possible for users of organizations to establish direct contact with them officially. Such an approach leads finally to the creation of library and archives of ideas, thoughts with organizational value. A system should be designed allowing question and answer communication between managers, professionals, experts. Automatically referring unanswered questions to appropriate experts, and holding online meetings and even physical meetings. Virtual training system should be implemented so the al people who suggestion system of are in different parts of the country be able to use organization's educational programs, intranet, bulletin boards, meetings, dialogue etc.

Mehdizadeh (2013) investigated the "factors affecting individual behavior, knowledge sharing" and summarizes that in current business condition, knowledge is one of the core competencies of the organizations that creates sustainable competitive advantage in them. So knowledge management is the focus of today's businesses. According to the researchers, the key enabler of knowledge management process in organizations is the process of sharing knowledge. Knowledge is basically created by the people in an organization. Knowledge sharing is the main processes of converting individual knowledge into organizational knowledge. Implementation of knowledge management will not happen in organizations unless employees share their knowledge. Therefore, this study is designed with the aim of investigating the factors influencing the behavior of knowledge sharing among employees of Iran Khodro company of Khorasan (car assembly plant) using the theory of behavior. The methodology of this paper is descriptive and correlate. Questionnaires were distributed between 310 employees and a total of 220 questionnaires were collected. Reliability and validity, by using factor analysis and Cronbach's alpha was approved and with the help of structural equation modeling (SEM) and using the software LISREL, models and hypotheses were tested. Prediction power of the model obtained for behavior of knowledge sharing is $(\mathrm{R} 2=0.56)$. The results indicated that behavior of knowledge sharing among employees of Iran Khodro Company of Khorasan considerably is influenced by the perceived behavioral control proportioned to the knowledge sharing intention which shows the behavior of knowledge sharing among employees is not completely under their control. Also the results showed that the attitude variable to knowledge sharing proportionately explains the intention of knowledge sharing but the correlation between subjective norm variable and perceived behavioral control with the intention of sharing knowledge was not confirmed.

\section{The Definition of Concepts}

Marketing knowledge sharing: If people share information, views, effective practices, experiences, tastes, and lessons learned, performance of different parts of organization will increase and also they can share common or non-common sense. Knowledge sharing is different from distribution, dissemination and transfer of knowledge. Someone who shares knowledge is not willing to disseminate just his own information, but he is ready to understand and learn the target knowledge. Knowledge sharing is a voluntary release of the skills acquired and individual experiences to the other organization members (Hamidizadeh \& Azizi, 2009).

Competitive Advantage: Occurs when a company, in indexes or a combination of indexes, reaches progress, development and capabilities giving it a superiority to the competitors such as access to natural resources, or highly skilled manpower, equipment or information technology (Hill\& Jones, 2010) 
Hypothesis: Marketing knowledge sharing has a significant relationship with developing competitive advantage in the petrochemical industry.

\section{Research Methodology}

This research is an applied research in this objective and in data collection method is the descriptive and correlative and like many similar descriptive studies, for the collection of required data, library and documentary study, interview and questionnaire is used. The target population in this study is Iran's petrochemical industry with the Arak petrochemical industry as the sample. The Petrochemical customers are considered based on type of classified products and filled into each category. So the sample can properly represent population that is Iran's petrochemical industry. In this study, the following equation is used to determine the sample size

$$
n=\frac{z_{\frac{\alpha}{r}}^{r} \bar{p}(1-\bar{p})}{E^{r}}
$$

The sample size was estimated 90 people. The method is stratified random sampling one. A standard questionnaire was used to collect data. Variable of marketing knowledge sharing includes three components (its worth for the individual and the organization, its culture in the organization the executives supporting it and 17 items (Moghimi \& Ramazan, 2011) and variable of developing competitive advantage consists of 4 components (quality, innovation, customer responsiveness and efficiency) and 16 questions (Hill and Jones, 2010). Logical validity (face and content) of questionnaires was reviewed and approved through several university professors and experts in this industry. Also construct validity was reviewed and approved by confirmatory factor analysis using AMOS software. Cronbach's alpha coefficient was obtained over 0.7 for variables that indicated internal consistency of items and acceptable reliability of the questionnaire. Hypothesis test using univariate linear regression was performed with application of the software SPSS.

\subsection{Research Findings}

Normality test of distribution of views for variables: In order to evaluate the normality of the research dimensions, Kolmogorov-Smirnov test was used.

H0: Distribution of research variables is normal.

H1: Distribution of research variables is not normal.

Table 1. Investigating normality of dimensions using the Kolmogorov-Smirnov test

\begin{tabular}{lll}
\hline & Marketing knowledge sharing & Developing competitive advantage \\
\hline Static value of Kolmogorov-Smirnov & 1.01 & 0.59 \\
Significant level (p-value) & 0.25 & 0.88 \\
\hline
\end{tabular}

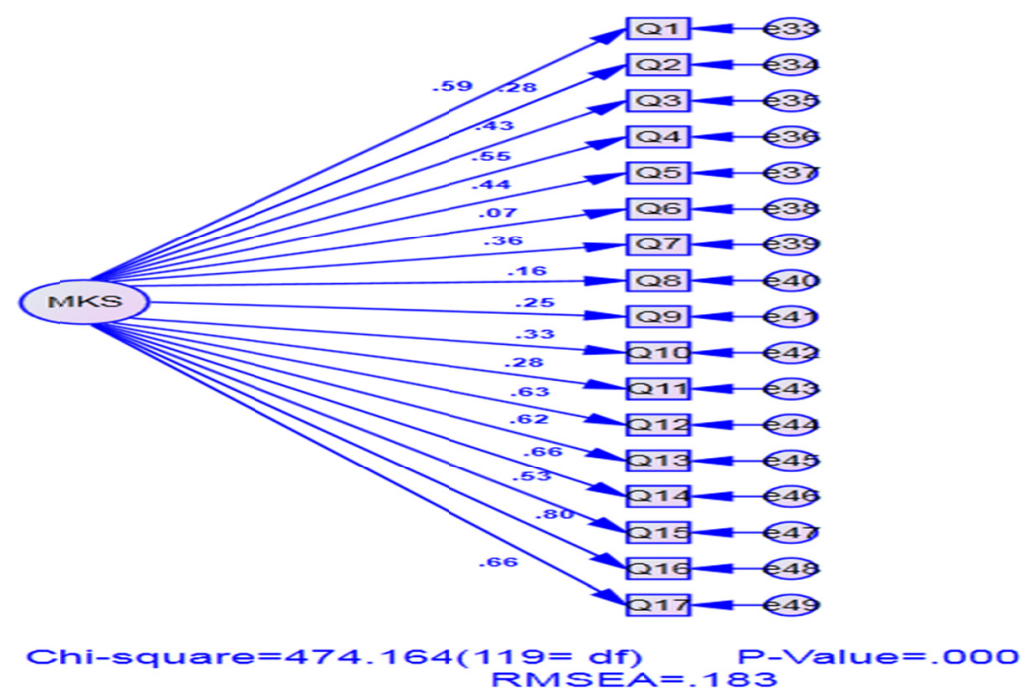

Figure 1. Results of marketing knowledge sharing (MKS) before modifying the model 
The result of Table 1 represents the normality of distribution of respondents' views.

\subsection{Confirmatory Factor Analysis}

In this section, factor analysis of variables will be investigated and necessary modifications on the model are done.

The results of marketing knowledge sharing (MKS) before the model modification

As you can see in Figure 1 The results of marketing knowledge sharing (MKS) has been shown before modifying the model as well as the table of appropriate indicators of model for the latent variable of individual factors is displayed. Then, we will display modified model and the table of modified indicators.

Table 2. Appropriate indices of model for latent variable of management of knowledge sharing before modifying the model

\begin{tabular}{lll}
\hline Index & Calculated value & Appropriate value \\
\hline$\chi^{2}$ & 474.16 & ---- \\
$d f$ & 119 & ----- \\
$\chi^{2} / d f$ & 3.98 & $\chi^{2} / d f<3$ \\
$R M S E A$ & 0.18 & $R M S E A<0.06$ \\
$C F I$ & 0.42 & $C F I>0.9$ \\
$I F I$ & 0.44 & $I F I>0.95$ \\
$G F I$ & 0.63 & $G F I>0.9$ \\
$A G F I$ & 0.52 & $A G F I>0.9$ \\
$N F I$ & 0.37 & $N F I>0.9$ \\
\hline
\end{tabular}

The results of the indices of appropriateness of model for the latent variable of management knowledge sharing before modifying the model indicated the non-appropriateness of model, as it can be observed that RMSEA statistic value is more than 0.06 , and CFI index less than 0.9 . Also the ratio of chi-square statistic to degrees of freedom has been greater than 3. This non-appropriateness is also true of the other indices. So the model was modified.

\subsection{The Results of Marketing Knowledge Sharing (MKS) After Modifying Model}

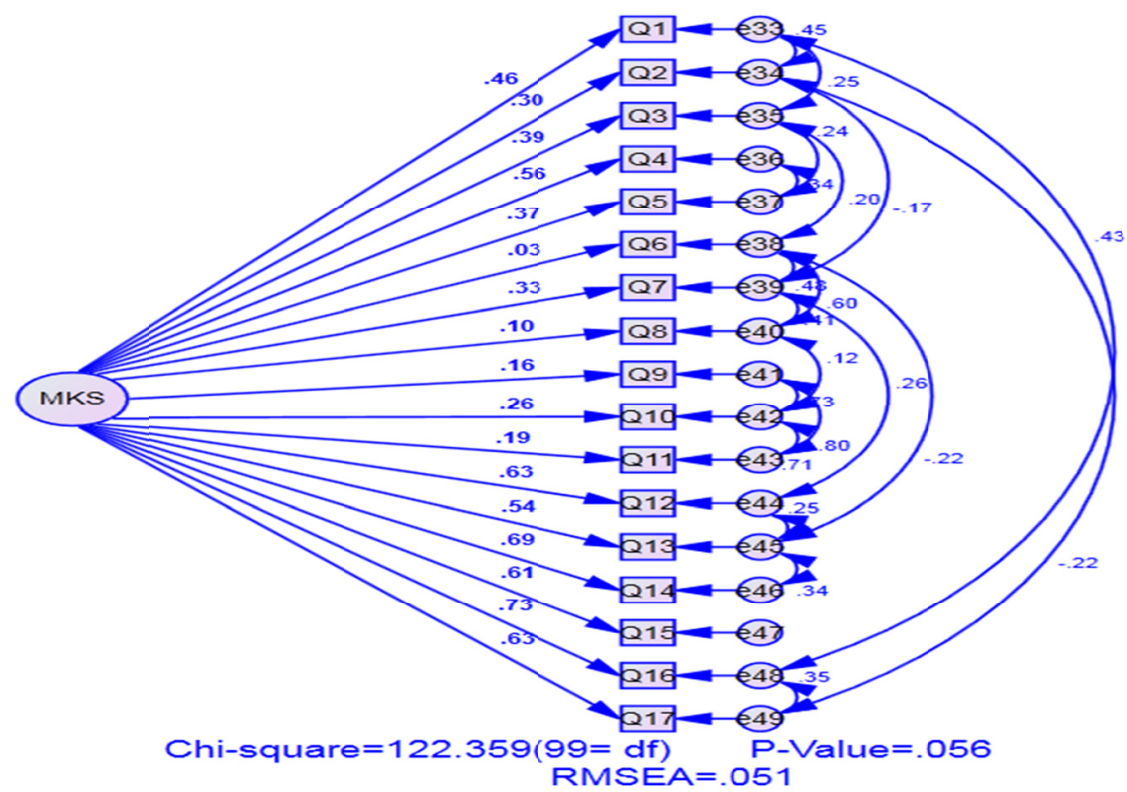

Figure 2. Results of marketing knowledge sharing (MKS) before modifying the model 
Table 3. Appropriate indices of model for latent variable of management of knowledge sharing before modifying the model

\begin{tabular}{ccc}
\hline Index & Calculated value & Appropriate value \\
\hline$\chi^{2}$ & 122.36 & ---- \\
$d f$ & 99 & ---- \\
$\chi^{2} / d f$ & 1.24 & $\chi^{2} / d f<3$ \\
$R M S E A$ & 0.05 & $R M S E A<0.06$ \\
$C F I$ & 0.96 & $C F I>0.9$ \\
$I F I$ & 0.96 & $I F I>0.95$ \\
$G F I$ & 0.87 & $G F I>0.9$ \\
$A G F I$ & 0.8 & $A G F I>0.9$ \\
$N F I$ & 0.84 & $N F I>0.9$ \\
\hline
\end{tabular}

The results of the indices of appropriateness of model for the latent variable of marketing knowledge sharing after modifying the model indicated the appropriateness of the model, as it can be observed that RMSEA statistic value is less than 0.06 , and CFI index has been more than 0.9 . Also the ratio of chi-square statistic to degrees of freedom has been less than 3 .

\subsection{The Results of Competitive Advantage (CAP) Before Modifying the Model}

As you can see in Figure 3, the results of competitive advantage (CAP) before modifying the model has been shown as well as the table of indicators of appropriateness of model for the latent variable of individual factors is displayed. Then, we will display modified model and the table of modified indicators.

Table 4. Appropriate indices of model for latent variable of competitive advantage before modify the model

\begin{tabular}{lll}
\hline Index & Calculated value & Appropriate value \\
\hline$\chi^{2}$ & 354.35 & ---- \\
$d f$ & 104 & ---- \\
$\chi^{2} / d f$ & 3.41 & $\chi^{2} / d f<3$ \\
$R M S E A$ & 0.16 & $R M S E A<0.06$ \\
$C F I$ & 0.69 & $C F I>0.9$ \\
$I F I$ & 0.69 & $I F I>0.95$ \\
$G F I$ & 0.63 & $G F I>0.9$ \\
$A G F I$ & 0.52 & $A G F I>0.9$ \\
$N F I$ & 0.62 & $N F I>0.9$ \\
\hline
\end{tabular}

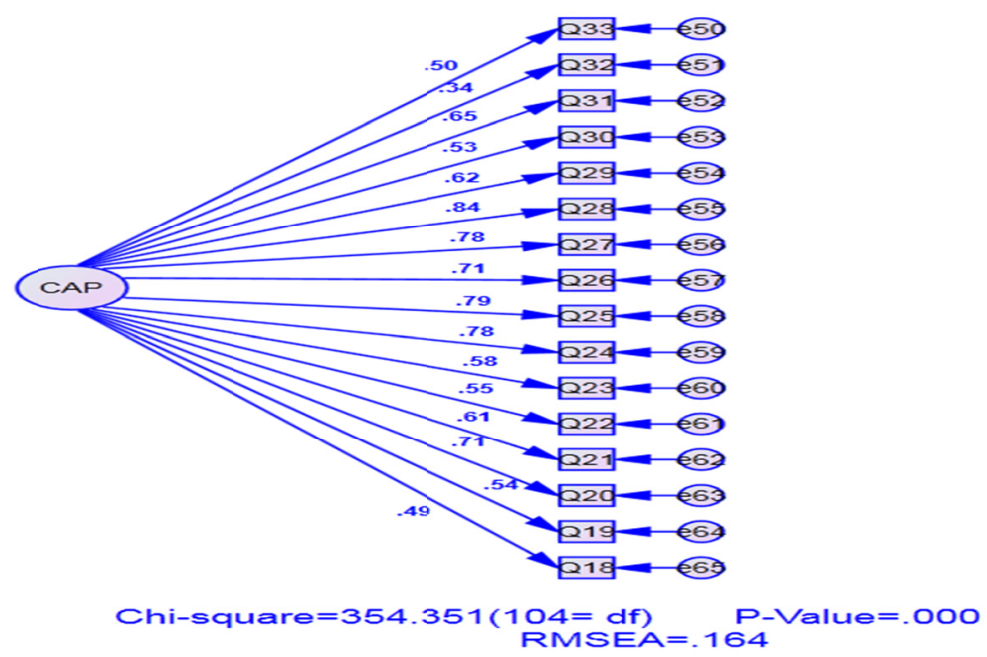

Figure 3. Results of competitive advantage (CAP) before modifying the model 
The results of the indices of appropriateness of model for the latent variable of competitive advantage before modifying the model indicated the non-appropriateness of model, as it can be observed that RMSEA statistic value is more than 0.06 , and CFI index less than 0.9. Also the ratio of chi-square statistic to degrees of freedom has been greater than 3 . This non-appropriateness is also true of the other indices. So the model was modified.

\subsection{The Results of the Competitive Advantage (CAP) After Modifying the Model}

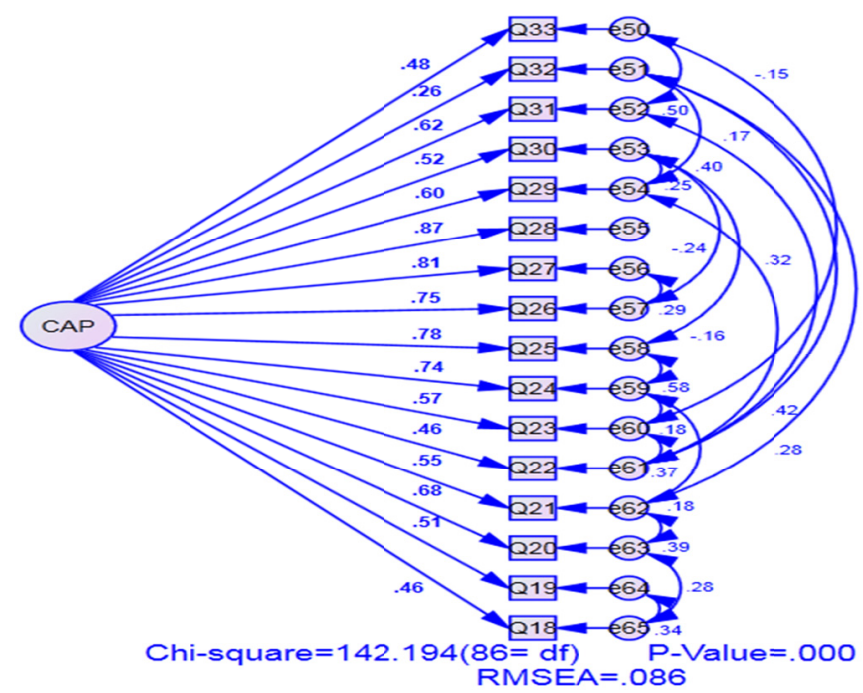

Figure 4. Results of marketing knowledge sharing (MKS) before modifying the model

Table 5. Appropriate indices of model for latent variable of competitive advantage before modifying the model

\begin{tabular}{lll}
\hline Index & Calculated value & Appropriate value \\
\hline$\chi^{2}$ & 142.19 & ---- \\
$d f$ & 86 & ---- \\
$\chi^{2} / d f$ & 1.65 & $\chi^{2} / d f<3$ \\
$R M S E A$ & 0.08 & $R M S E A<0.06$ \\
$C F I$ & 0.93 & $C F I>0.9$ \\
$I F I$ & 0.93 & $I F I>0.95$ \\
$G F I$ & 0.84 & $G F I>0.9$ \\
$A G F I$ & 0.74 & $A G F I>0.9$ \\
$N F I$ & 0.85 & $N F I>0.9$ \\
\hline
\end{tabular}

The results of the indices of appropriateness of model for the latent variable of competitive advantage after modify the model indicated the appropriateness of model, as it can be observed that RMSEA statistic value is less than 0.06 , also CFI index more than 0.9. Also the ratio of chi-square statistic to degrees of freedom has been less than 3 .

Investigating the position of research variables

To compare the research dimensions with the value of their test, a single sample t-test was used that its results are in Table 6.

Table 6. Single-sample t-test to investigate the position of variables

\begin{tabular}{|c|c|c|c|c|c|c|}
\hline \multirow[t]{2}{*}{ Variables } & \multicolumn{4}{|c|}{ Value of test $=3$} & \multicolumn{2}{|c|}{ Confidence interval } \\
\hline & $\begin{array}{l}\mathrm{t} \\
\text { value }\end{array}$ & $\begin{array}{l}\text { Degree of } \\
\text { freedom }\end{array}$ & p-value & $\begin{array}{l}\text { Difference of } \\
\text { mean }\end{array}$ & $\begin{array}{l}\text { Lower } \\
\text { bound }\end{array}$ & $\begin{array}{l}\text { upper } \\
\text { bound }\end{array}$ \\
\hline Marketing knowledge sharing & $* 2.24$ & 89 & 0.027 & 0.12 & 0.01 & 0.23 \\
\hline $\begin{array}{l}\text { Developing } \\
\text { advantage }\end{array}$ & $* * 2.9$ & 89 & 0.005 & 0.19 & 0.06 & 0.32 \\
\hline
\end{tabular}


Single sample t-test results showed that at the level of error of five percent, all aspects of the research with value of the test (ie 3) had a significant difference so that their mean is higher than the value of the test.

The research hypothesis test: marketing knowledge sharing has a significant relationship with developing competitive advantage in the petrochemical industry.

To evaluate the effect of marketing knowledge sharing variable on developing competitive advantage, first, the assumption of non- correlation between the errors was investigated using Durbin-Watson test.

Table 7. Results of Durbin-Watson test and appropriateness of model

\begin{tabular}{|c|c|c|c|c|c|}
\hline $\begin{array}{l}\text { Coefficient } \\
\text { determination }\end{array}$ & of & $\begin{array}{l}\text { Squared coefficient of } \\
\text { determination }\end{array}$ & $\begin{array}{l}\text { Modified coefficient of } \\
\text { determination }\end{array}$ & $\begin{array}{l}\text { Estimated } \\
\text { standard error }\end{array}$ & $\begin{array}{l}\text { Durbin-Watson } \\
\text { value }\end{array}$ \\
\hline 0.57 & & 0.32 & 0.31 & 8.06 & 2.13 \\
\hline
\end{tabular}

Since Durbin-Watson value is between 1.5 and 2.5 therefore the hypothesis of non- correlation between errors is not rejected. On one hand, normality of errors in Figure 1 also shows the normality holds. So we can investigate marketing knowledge sharing effect on developing competitive advantage using univariate regression.

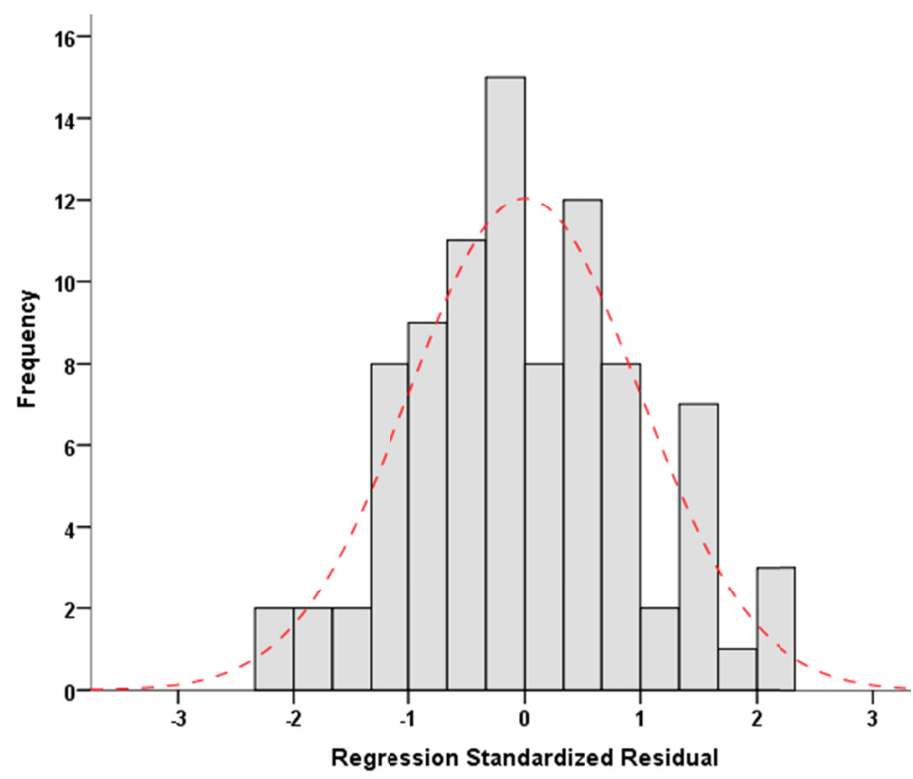

Figure 1. Normality of errors of independent variable in marketing knowledge sharing model and developing competitive advantage

Table 8. Effect of variable of marketing knowledge sharing on developing competitive advantage

\begin{tabular}{cccccccc}
\hline & $\begin{array}{c}\text { Non-standard } \\
\text { coefficient }\end{array}$ & $\begin{array}{c}\text { standard } \\
\text { coefficient }\end{array}$ & & & \multicolumn{2}{c}{$\begin{array}{c}\text { Confidence interval of } \\
95 \% \text { for non-standard } \\
\text { coefficients }\end{array}$} \\
\hline Variable & $\mathrm{B}$ & $\begin{array}{c}\text { Standard } \\
\text { error }\end{array}$ & Beta & $\begin{array}{c}\mathrm{t} \\
\text { value }\end{array}$ & $\begin{array}{c}\text { Significant } \\
\text { level }\end{array}$ & $\begin{array}{c}\text { Lower } \\
\text { bound }\end{array}$ & upper bound \\
\hline $\begin{array}{c}\text { Fix } \\
\begin{array}{c}\text { Marketing knowledge } \\
\text { sharing }\end{array}\end{array}$ & 17.91 & 5.18 & ---- & 3.46 & 0.001 & 7.62 & 28.19 \\
\hline
\end{tabular}

As you can see in table 8, given that the $\mathrm{t}$-statistic is greater than $1.96(\mathrm{t}=6.48)$, the relationship between these two variables has been significant at $5 \%$ error level. $(P-$ Value $<0.05)$. So the relationship between the competitive advantage and marketing knowledge sharing is direct and positive. This means that the more the knowledge sharing between the various parts of organizations increases, the more competitive advantage of the organization increases. Standard regression coefficient (0.57) also so specifies the share of independent variable 
in explaining the changes of dependent variable that for every one unit increase in variable of marketing knowledge sharing, competitive advantage increases 0.57 percent.

\section{Conclusion}

Here, a summary of the findings is presented:

Single sample t-test results showed that at the level of five percent error, all aspects had significant difference with the value of the test (ie 3) so that their mean has been more than the value of the test.

As the results showed, given that the $\mathrm{t}$-statistic has been more than $1.96(\mathrm{t}=6.48)$, the relationship between these two variables has been significant at the $5 \%$ error level. $(P$-Value $<0.05)$. So the relationship between competitive advantage and marketing knowledge sharing is direct and positive. This means that the more the knowledge sharing between the various parts of organizations increases, the more competitive advantage of the organization increases. Standard regression coefficient (0.57) also so specifies the share of independent variable in explaining the changes of dependent variable that for every one unit increase in variable of marketing knowledge sharing, competitive advantage increases 0.57 percent.

\section{Suggestion}

Competitive advantage is one of the basic concepts in international business that determines the competitive position of the organization and provides it with a defensive position against its competitors. There are two types of competitive advantage for the organization. Cost advantage and distinctive advantage. Cost advantage for organizations is important because all organizations can have the price competition and ultimately this will be a loss to the organization while distinctive advantage creates a positive factor for organization from which the organization can benefit as long as this advantage persists. Knowledge sharing, especially knowledge of marketing makes such a distinction to the organization. The more the knowledge sharing and cooperation of works to achieve it, the more durable the organization's distinctions as compared with its competitors . So organizations pay attention to knowledge sharing as a principle and factor for progress and developing competitive advantage of organization so they are the priorities of modern organizations. Knowledge sharing may be done orally or written, regular or irregular, delayed or immediate, precise and in-depth or general and limited. This may be done in three levels with colleagues, with the managers and subordinates. All cases should be investigated in the organization to improve each of them at the best possible level.

\section{References}

Bartol, K., \& Srivastava, A. (2002). Encouraging knowledge sharing: The role of organisational rewards. Journal of Leadership and Organisation Studies, 9(1), 64-76.

Bechina, A. A., \& Bommen, T. (2006). Knowledge sharing practices: Analysis of a global Scandinavian consulting company', The Electronic Journal of Knowledge Management, 4(2), 109 - 116.

Bender, S., \& Fish, A. (2000). The transfer of knowledge and the retention of expertise: the continuing need for global assignments. Journal of Knowledge Management, 4(2), 125-137.

Hamidizadeh, M. R., \& Azizi, S. (2009). Factors Affecting Marketing Knowledge Sharing (MKS): The Case of Iranian Food and Auto Industries. Indian Journal of Marketing, 39(12), 40-49.

Hill, C. W., \& Jones, G. R. (2010). Strategic management theory: An integrated approach (9th Eds.). Mason, OH: South-Western/Cengage Learning.

Mahdizadeh, R. (2013). Reviews the factors influencing individual behavior, knowledge sharing (Case study: Khorasan employees IKCO), College of Administrative Sciences and Economics.

Moghimi, S. M., \& Ramazan, M. (2011). Journal of Management, 9, published Rahdan, Tehran.

Nonaka, I. (1995). The knowledge-creating company: How Japanese companies create the dynamics of innovation. Oxford: Oxford University Press.

Rezai, D., et al. (2011). Investigating the impact of competitive advantage in creating competitive advantage, Journal of Outlook of Business Administration.

Rifua, S., Tajdaran, M., \& Rezaie, S. S. (2013). Positioning infrastructure components of implementing the sharing of knowledge in the insurance industry. Research of Library and Academic Information, 47(3), 325-346.

Wasko, M. M., \& Faraj, S. (2000). It is what one does: Why people participate and help others in electronic communities of practice. Journal of Strategic Information Systems, 9, 155-173. 


\section{Copyrights}

Copyright for this article is retained by the author(s), with first publication rights granted to the journal.

This is an open-access article distributed under the terms and conditions of the Creative Commons Attribution license (http://creativecommons.org/licenses/by/4.0/). 